\title{
Soluble Form of Transferrin Receptor as A Biomarker of Ineffective Erythropoiesis and Iron Overload in Pediatric Egyptian Patients with $\beta$-Thalassemia
}

\author{
MOHAMED H. MEABED, M.D.*; AYMAN S. SOLIMAN, M.D.**; DINA A. EZZAT, M.D.*; \\ SAHAR S. ABD-ELHALIM, M.D.* and DINA H. EL-DAHSHAN, M.D.*** \\ The Departments of Pediatrics*, Physiology** and Clinical Pathology***, Faculty of Medicine, Beni Suef University, Egypt
}

\begin{abstract}
Background: Beta-thalassemias ( $\beta$-thalassemias) are a group of inherited blood disorders caused by reduced or absent synthesis of the beta chains of hemoglobin resulting in variable phenotypes ranging from severe anemia to clinically asymptomatic individuals. Thalassemia is the commonest hereditary hemolytic anemia in Egypt. Iron overload is a major complication of repeated blood transfusion in patients with thalassemia. Soluble Transferrin Receptor (sTfR), one of the main regulators of cellular iron homeostasis, is the truncated form of the tissue receptor.
\end{abstract}

Aim of Study: This work was conducted to study the pathophysiology of iron overload in children with $\beta$ thalassemia intermedia and thalassemia major and explore the possible utility of Soluble Transferrin Receptor (sTfR) for the evaluation of iron overload and ineffective erythropoiesis in pediatric Egyptian patients with $\beta$ thalassemia major, $\beta$-thalassemia intermedia and comparing this with the controls.

Patients and Methods: This study was conducted on sixty $\beta$-thalassemia patients ( $30 \beta$-thalassemia major and $30 \beta$ thalassemia intermedia) together with 30 age and sex matched controls. Patients were selected from the outpatient clinics of the Pediatric Hematology Unit and the Inpatients of Pediatric Department; Faculty of Medicine, Beni Suef University Hospital during the year 2017. Patients and control were subjected to clinical evaluation and complete blood count along with serum ferritin and sTfR levels by Enzyme-Linked Immunosorbent Assay (ELIZA) technique.

Results: Both serum ferritin and sTfR levels were significantly higher in patients compared with controls and in patients with thalassemia major compared with those with thalassemia intermedia. Serum ferritin and sTfR levels were significantly positively correlated with patients' age and with each other. Each of them was negatively correlated with age of disease onset, frequency of blood transfusions and with hemoglobin level.

Conclusion: Serum levels of ferritin and soluble transferrin receptor were significantly higher in both thalassemic groups in comparison to control group.

Correspondence to: Dr. Mohamed H. Meabed, The Department of Pediatrics, Faculty of Medicine, Beni Suef University, Egypt
Key Words: Soluble Transferrin Receptor (sTfR) - Iron overload - Ineffective erythropoiesis - Thalassemia major - Thalassemia intermedia.

\section{Introduction}

BETA-THALASSEMIA syndromes are a group of hereditary blood disorders characterized by reduced or absent beta globin chain synthesis, resulting in reduced $\mathrm{Hb}$ in Red Blood Cells (RBC), decreased RBC production and anemia [1].

Thalassemias are genetic disorders in globin chain production, in individuals with $\beta$-thalassemia, there is either a complete absence of B-globin gene production ( $\beta 0$-thalassemia) or partial reduction $(\beta+$-thalassemia). In alpha thalassemia, alpha globin gene production is either absent or partially reduced [2].

Although $\beta$-thalassemia has more than 200 mutations, most are rare, approximately twenty common alleles constitute eighty percentage of known thalassemias worldwide, three percentage of world's population carries genes for $\beta$ thalassemia, and in Southeast Asia, five to ten percentage of population carries genes for alpha thalassemia [3].

The central mechanism underlying the pathophysiology of the $\beta$-thalassemias can be related to the deleterious effects of imbalanced globin chain synthesis on erythroid maturation and survival [2] An imbalance of the $\alpha$-/non $\alpha$-globin chains leads to an excess of unmatched $\alpha$-globin which precipitates out, damaging membrane structures leading to accelerated apoptosis and premature destruction of the erythroid precursors in the bone marrow such condition known as ineffective erythropoiesis [4]. 
The severe ineffective erythropoiesis stimulates production of erythropoietin resulting in erythroid marrow expansion to as much as 30 times the normal level [5]. The marked expansion of bone marrow erythroid production and the extramedullary hematopoiesis that occurs in various tissues such as the thorax and paraspinal region cause the osseous deformities that are hallmarks of thalassemia major, such as skull, facial, and sinus deformities [6].

Transferrin is iron carrier protein that consist of two lobes, the $\mathrm{N}$ and $\mathrm{C}$ lobes, which can each bind a $\mathrm{Fe}+$ ion, transferrin binds to its receptor (TfR) which mediate iron delivery to cells through an endocytotic pathway. Receptor binding facilitates iron release from the $\mathrm{C}$-lobe but impedes iron release from the N-lobe [7].

Transferrin receptors are transmembrane proteins present on the surface of most cells; the iron required for cellular metabolism is acquired via transferrin receptors [8].

Soluble transferrin receptor (sTfR) originate mostly form erythroblasts and to less extent from reticulocytes, the usefulness of (sTfR) has been implicated in several clinical situations mainly as a marker of accelerated erythropoiesis or iron deficiency [9].

Transferrin receptor concentrations are increased in disorders with expanded erythropoiesis, such as hemolytic anemias and in conditions associated with ineffective erythropoiesis, such as myelodysplastic syndromes and megalobastic anemia $[10,11]$.

A raised serum tansferrin receptor (sTfR) level is useful as a marker of iron deficiency as it is unaffected by inflammation. As thalassemia is associated with ineffective erythropoiesis and therefore an increase in the serum transferrin level [8].

Study of erythropoiesis in selected thalassemia intermedia patients has shown that for a given hemoglobin value, hemoglobin F has an independent regulatory effect on erythropoietin release and erythropoiesis expansion, patients with high $\mathrm{HbF}$ (>40\%) were found to have significantly greater serum erythropoietin and Soluble transferrin receptor level (sTfR) than low $\mathrm{HbF}(<40 \%)$ patients at similar hemoglobin concentration. There is clear evidence that $\mathrm{sTfR}$ reflects total erythropoiesis, but it is still unclear whether differences in the ratio of ineffective to effective erythropoiesis can affect its level [12]. This work was conducted to study the pathophysiology of iron overload in children with 3 -thalassemia intermedia and thalassemia major and explore the possible utility of soluble transferrin receptor (sTfR) for the evaluation of iron overload and ineffective erythropoiesis in pediatric Egyptian patients with (3-thalassemia major, (3-thalassemia intermedia.

\section{Patients and Methods}

\section{Patients:}

The present study was conducted on 60 thalassemia patients (30 (3-thalassemia major and 30 (3-thalassemia intermedia) together with 30 age and sex matched controls. They were selected from the Pediatric Department, Hematology Unit, Faculty of Medicine, Beni Suef University Hospital. This study was done during the year 2017. Informed consents were obtained from the children's guardians for all participants.

\section{Subjects were divided into three groups:}

- Group (I): 30 patients with (3-thalassemia major; $14(47 \%)$ males and $16(53 \%)$ females, their ages ranged from 1-12 years old.

- Group (II): 30 Patients with (3-thalassemia intermedia; $19(63 \%)$ males and 11 (37\%) females, their ages ranged from 3-10 years old.

- Group (III): Control group: 30 normal healthy subjects; 18 (60\%) males and $12(40 \%)$ females, their ages ranged $1-12$ years old.

\section{Methods:}

\section{All subjects were subjected to the following:}

Full history taking: Including history of consanguinity, frequency of regular blood transfusion, chelation therapy, duration of illness, family history of hematological disease, history of splenectomy.

Full clinical examination: General examination, anthropometric assessment as well as a pedigree done for all the patients. These data collected using a standardized sheet and completed for all study subjects.

All patients included in the study were on the following treatment:

Folic acid with a dose of (65-200 microg/day), L-carnitine with a dose of $(50 \mathrm{mg} / \mathrm{kg} /$ day $)$, those with high serum ferritin level were on oral iron chelation therapy in the form of deferiprone with a dose of $(75 \mathrm{mg} / \mathrm{kg} /$ day $)$ or deferasirox with a dose of $(10-40 \mathrm{mg} / \mathrm{kg} /$ day $)$. 


\section{Laboratory investigations:}

Sample collections:

Peripheral blood samples were withdrawn from each child. Each sample was divided into two parts: The first part was collected on EDTA and used for the complete blood count, while the second part was collected in a plain tube, left to clot, centrifuged and the serum separated and stored at $-80^{\circ} \mathrm{c}$ for later use.

Biochemical assays: Complete Blood Count (CBC), Hemoglobin electrophoresis, Serum ferritin level was quantitatively determined by Enzyme Linked Immunosorbent Assay (ELISA), Reticulocytic count and Hemoglobin level pre and post therapy were done.

Serum soluble transferrin receptor (sTfR) was quantitatively determined by Enzyme Linked Immunosorbent Assay (ELISA) using monoclonal antibodies specific for (sTfR) using kit manufactured by Bio Vendor Research and Diagnostic Products, D.69120 Heidelberg, Germany, Version 4102100915 (Lot number: AK0015MARl 6007). Reference ranges were $1.0-2.9 \mathrm{ug} / \mathrm{ml}$ when using this assay values increased in thalassemia. Readings were done at wave length 450nm using an ELIZA reader within 5-10 minutes [13].

All previously mentioned biochemical assays were done for all samples of the study groups. For all biochemical assays, the manufacturer instructions were followed.

\section{Statistical analysis:}

Data was collected, verified, revised then edited on personal computer. Data were coded and entered using the statistical package SPSS (Statistical Package for the Social Science; SPSS Inc., Chicago, IL, USA) version 22. $p$-values less than 0.05 were considered as statistically significant.

\section{Results}

Data of the present study showed that thalassemia major manifestations appear at significantly earlier age of onset than thalassemia intermedia $(0.56 \pm 0.17,3.45 \pm 0.93)$ respectively $p>0.01$. Patients of thalassemia major group had significant more frequent blood transfusions (times/year) than those of thalassemia intermedia group (13.4 \pm 0.66 , $1.90 \pm 0.31) p<0.01$ (Table 1).

Results showed statistically significant higher usage of iron chelator drugs among thalassemia major patients compared to thalassemia intermedia group [29 (96.7\%) \& $27(85 \%)]$ respectively $p<0.01$ (Table 1).
In addition, data of the present study revealed higher significant differences regarding splenectomy and hepatomegaly [21 (70\%) \& $25(83 \%)$ ] respectively in thalassemia major patients as compared to those of thalassemia intermedia [6 (20\%) $\& 23(76.66 \%)$ ] respectively $p<0.05$ (Table 1 ).

Splenomegaly in patients of thalassemia major is $9(30 \%)$ which is significantly lower than that of thalassemia intermedia $21(70 \%)$ obviously as a result of more splenectomy were done for thalassemia major patients $p<0.05$ (Table 1).

Table (1): Statistical comparison between Thalassemia Major (TM) and Thalassemia Intermedia (TI) patients regarding different clinical data.

\begin{tabular}{llll}
\hline Variables & $\begin{array}{c}\mathrm{TM}(\mathrm{N}=30) \\
\text { Mean } \pm \mathrm{SD}\end{array}$ & $\begin{array}{c}\mathrm{Tl}(\mathrm{N}=30) \\
\text { Mean } \pm \mathrm{SD}\end{array}$ & $\begin{array}{c}p^{-} \\
\text {value }\end{array}$ \\
\hline - Age of disease onset (years) & $0.56 \pm 0.17$ & $3.45 \pm 0.93$ & $<0.01^{* *}$ \\
- Frequency of blood & $13.4 \pm 0.66$ & $1.90 \pm 0.31$ & $<0.01^{* *}$ \\
$\quad$ transfusions (times/year) & & & \\
- Iron chelation: & & & \\
$\quad$ No chelation & $1(5 \%)$ & $3(15 \%)$ & $<0.01^{* *}$ \\
$\quad$ Deferasirox & $26(80 \%)$ & $27(85 \%)$ & \\
$\quad$ Deferiprone & $3(15 \%)$ & & \\
- Spleen: & & & \\
$\quad$ Normal & & $3(10 \%)$ & $<0.01^{* *}$ \\
$\quad$ Splenomegaly & $9(30 \%)$ & $21(70 \%)$ & \\
$\quad$ Splenectomy & $21(70 \%)$ & $6(20 \%)$ & \\
- Liver: & & & \\
$\quad$ Normal & $5(17.7 \%)$ & $7(23.33 \%)$ & $<0.05^{*}$ \\
$\quad$ Hepatomegaly & $25(83.3 \%)$ & $23(76.66 \%)$ & \\
\hline * : Significant; $p$-value $<0.05$. & & & \\
$* *$ Highly significant; $p$-value $<0.01$. & &
\end{tabular}

Current study data revealed statistically significant lower $\mathrm{HbA}$, higher $\mathrm{HbA} 2$ and $\mathrm{Hb} \mathrm{F}$ in thalassemia major $(32.3 \pm 38.3,5.3 \pm 3.5,62.4 \pm 28.5)$ respectively as compared to thalassemia intermedia patients $(65.2 \pm 35.2,2.5 \pm 2.0,32.3 \pm 36.0)$ respectively $p<0.01$ (Table 2 ).

On the other hand, there were no significant differences concerning the WBCs count, mean $\mathrm{Hb}$ level, MCV and PLT count among both beta thalassemic groups $p>0.05$ (Table 2).

Table (2): Statistical comparison between Thalassemia Major (TM) and Thalassemia Intermedia (TI) groups according to the laboratory parameters.

\begin{tabular}{|c|c|c|c|c|}
\hline Variables & $\begin{array}{c}\text { TM } \\
\text { Mean } \pm \text { SD }\end{array}$ & $\begin{array}{c}\mathrm{Tl} \\
\text { Mean } \pm \mathrm{SD}\end{array}$ & $\begin{array}{c}p- \\
\text { value }\end{array}$ & Sig. \\
\hline $\mathrm{WBC} \times 10^{3} / \mathrm{mL}$ & $10.1 \pm 6.3$ & $9.1 \pm 3.4$ & 0.557 & NS \\
\hline $\mathrm{Hb}(\mathrm{gm} / \mathrm{dl})$ & $7.3 \pm 1.1$ & $7.8 \pm 1.7$ & 0.244 & NS \\
\hline MCV (fL) & $66.6 \pm 8.4$ & $65.6 \pm 10.4$ & 0.329 & NS \\
\hline PLT X $10^{3} / \mathrm{mL}$ & $564.2 \pm 419.9$ & $511.3 \pm 226.3$ & 0.636 & NS \\
\hline $\operatorname{HbA}(\%)$ & $32.3 \pm 38.3$ & $65.2 \pm 35.2 \#$ & 0.001 & HS \\
\hline $\mathrm{HbA} 2(\%)$ & $5.3 \pm 3.5$ & $2.5 \pm 2.0 \#$ & 0.004 & HS \\
\hline $\mathrm{HbF}(\%)$ & $62.4 \pm 28.5$ & $32.3 \pm 36.0 \#$ & 0.002 & HS \\
\hline
\end{tabular}


Our results showed that there was statistically significant decrease in hemoglobin levels in all beta thalassemic patients as compared to control group $p<0.01$ (Table 3 ).

Serum ferritin and sTfR levels were significantly higher in thalassemia major patients $(1645 \pm 940$ $\mathrm{ng} / \mathrm{dl}, 6.3 \pm 0.6 \mathrm{~g} / \mathrm{n}$ ) respectively as compared to thalassemia intermedia patients $(791 \pm 300 \mathrm{ng} / \mathrm{dl}$, $4.7 \pm 0.7 \mathrm{y} / \mathrm{m}$ ) $p<0.01$ (Table 3).

Table (3): Statistical comparison between Thalassemia Major (TM), Thalassemia Intermedia (TI) and control groups regarding the laboratory data.

\begin{tabular}{|c|c|c|c|c|}
\hline Variables & $\begin{array}{c}\text { TM } \\
\text { Mean } \pm \text { SD }\end{array}$ & $\begin{array}{c}\mathrm{Tl} \\
\text { Mean } \pm \mathrm{SD}\end{array}$ & $\begin{array}{c}\text { Control } \\
\text { Mean } \pm \text { SD }\end{array}$ & $\begin{array}{c}p- \\
\text { value }\end{array}$ \\
\hline $\mathrm{Hb}(\mathrm{gm} / \mathrm{dl})$ & $7.3 \pm 1.1$ & $7.8 \pm 1.7$ & $12.3 \pm 0.7$ & $>0.01$ \\
\hline S.Ferritin (ng/dl) & $1645 \pm 933$ & $789 \pm 296 \#$ & 102士19\#@ & $>0.01$ \\
\hline STfRs $(\mu \mathrm{g} / \mathrm{ml})$ & $6.3 \pm 0.6$ & $4.7 \pm 0.7 \#$ & 2.3土0.8\#@ & $>0.01$ \\
\hline
\end{tabular}

\# : Significant as compared to TM.

@: : Significant as compared to TI.

While serum ferritin and sTfR levels were significantly higher in all beta thalassemic patients as compared to control group $p<0.01$ Fig. (1).

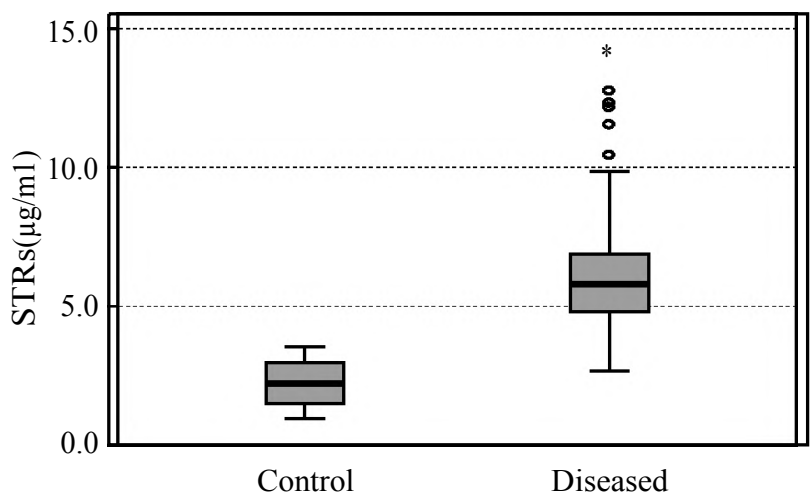

Fig. (1): Comparison between control group and diseased groups regarding soluble transferrin receptor (sTfR) level.

\section{Correlations:}

Data of the current work showed a strong negative correlation between STfR and both the age $(r=-0.711 \& p$-value $<0.01)$ and the hemoglobin level $(r=-0.872 \& p$-value $<0.01)$ among control group Fig. (2).

Results of the present work demonstrated that There was a strong positive correlation between sTfR ( $/ n /$ and both of serum ferritin (ng/dl) \& age among beta thalassemic patients. On the other hand, there was a strong negative correlation between sTfR ( $\mathrm{g} / \mathrm{h} \mathbf{l})$ and age of disease onset (years), $\mathrm{Hb} \%$ (gm/dl) and Frequency of blood transfusion (Table 4).
Serum ferritin level is positively correlated with patients age while it was negatively correlated with age of disease onset (years), $\mathrm{Hb} \%$ (gm/dl) and frequency of blood transfusion (Table 4).

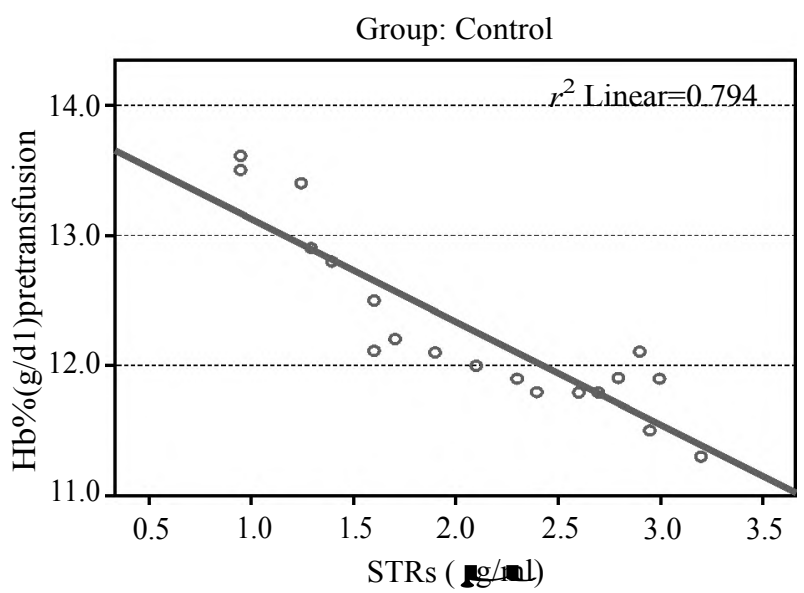

Fig. (2): Correlation between serum sTfR and hemoglobin levels among control group.

Table (4): Correlations between sTfR and serum ferritin and other variables among beta thalassemic patients.

\begin{tabular}{lcccc}
\hline & \multicolumn{2}{c}{$\operatorname{sTfRs}(\mu \mathrm{g} / \mathrm{ml})$} & \multicolumn{2}{c}{ S. Ferritin $(\mathrm{ng} / \mathrm{dl})$} \\
\cline { 2 - 5 } & $\begin{array}{c}\text { Pearson } \\
\text { correlation }\end{array}$ & $\begin{array}{c}p \text { - } \\
\text { value }\end{array}$ & $\begin{array}{c}\text { Pearson } \\
\text { correlation }\end{array}$ & $\begin{array}{c}p \text { - } \\
\text { value }\end{array}$ \\
\hline - Age (years) & $0.355^{* *}$ & $<0.01 * *$ & $0.443^{* *}$ & $<0.01^{* *}$ \\
$\begin{array}{l}\text { - Age of disease onset } \\
\text { (years) }\end{array}$ & $-0.439 * *$ & $<0.01 * *$ & $-0.426^{* *}$ & $<0.01^{* *}$ \\
- Frequency of blood & $-0.511^{* *}$ & $<0.01 * *$ & $-0.372 * *$ & $<0.01 * *$ \\
transfusion & $-0.896^{* *}$ & $<0.01 * *$ & $-0.688^{* *}$ & $<0.01 * *$ \\
- Hb\% (gm/d) & $0.771 * *$ & $<0.01 * *$ & & \\
- S. Ferritin & & & & \\
\hline
\end{tabular}

Data of the current work showed that there is strong negative correlation between STfR and hemoglobin $(r=0.997 \& p$-value $<0.01)$, and strong positive correlation between serum ferritin and age $(r=0.896 \& p$-value $<0.01)$ among thalassemia intermedia group Fig. (3).

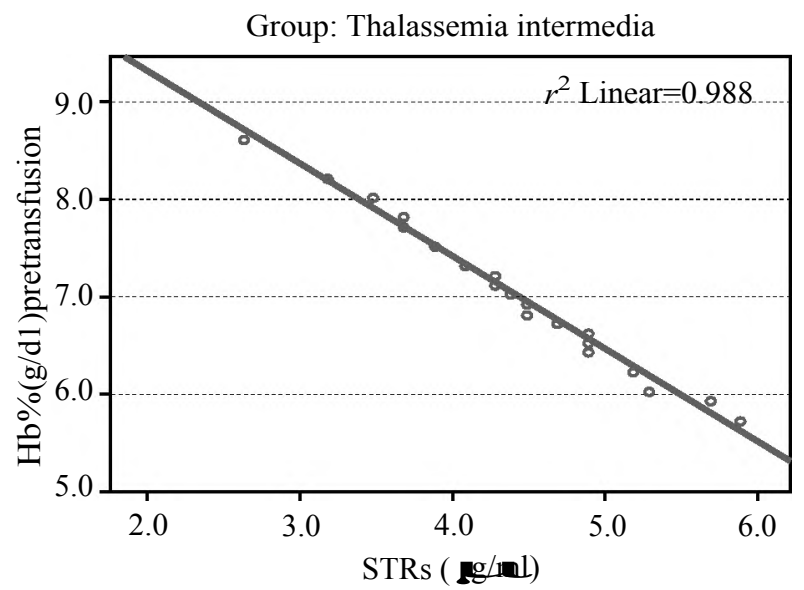

Fig. (3): Correlation between sTfR and hemoglobin among thalassemia intermedia group. 
Data of the present study showed that there is strong negative correlation between STfR and hemoglobin $(r=0.996 \& p$-value $<0.01)$ among thalassemia major group Fig. (4).

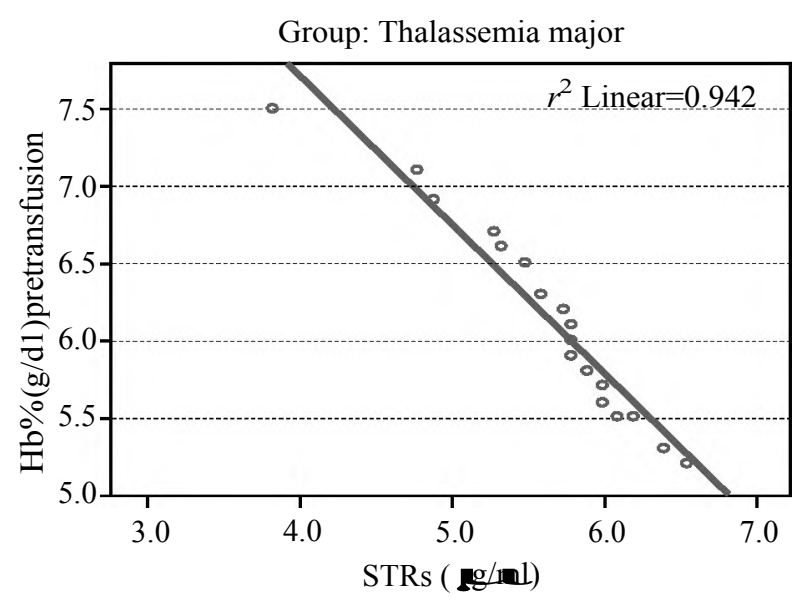

Fig. (4): Correlation between sTfR and hemoglobin among thalassemia major group.

\section{Discussion}

Beta Thalassemia is the most common chronic hemolytic anemia in Egypt (85.1\%) with an estimated carrier rate of $9-10.2 \%$ [14] .

The transferrin receptor (TfR) is the principal means by which various organ cellular constituents acquire iron, especially erythroid precursors in the bone marrow for hemoglobin production and the placenta for iron supply to the fetus. The TfR is a $188-\mathrm{kDa}$ transmembrane glycoprotein consisting of two 95-kDa polypeptide chains [13]

The TfR binds transferrin with increased avidity for diferric transferrin, whereas apotransferrin is minimally bound. Once transferrin binds to the receptor, the TfR-transferrin iron complex is internalized by formation of endocytic vesicles. Iron is released from the transferrin molecule within the vesicle under low $\mathrm{pH}$ conditions within the cell cytosol; released iron is then transported out of the vesicle into the cytoplasm via dimetaltransporter II, which is incorporated into the vesicle wall [15].

The remaining apotransferrin-TfR complex within the endocytic vesicle is transported back to the cell membrane, where apotransferrin is released back into the circulation, and TfR is incorporated into the cell membrane. Cell surface TfR concentration reflects iron requirements of the cell. When there is diminished intracellular iron available for a cell's metabolic requirements, cell surface TfR is upregulated in an effort to acquire more iron, while cell surface TfR is downregulated when there is sufficient intracellular iron content. Ferritin content of the cell is reciprocally regulated by a unique control mechanism at the level of translation [10] .

Serum contains a soluble Tfr (sTfR) molecule that circulates bound to transferrin and is a cleaved and truncated $85-\mathrm{kDa}$ form of the whole TfR molecule. The circulating sTfR level reflects total body $\mathrm{TfR}$ concentration, the major source of sTfR being bone marrow erythroid precursors. Ferrokinetic studies show a significant correlation between circulating sTfR levels and erythroid precursor mass [13].

The iron status reflects the balance among dietary iron uptake, its storage and mobilization, and its utilization. Iron overload is a common and serious problem in thalassemia, as well as in other hereditary and acquired hemolytic anemias. The main causes of iron overload in thalassemia are $\mathrm{Hb}$ instability, RBC transfusions, and increased iron absorption from the gastrointestinal tract [4].

This study aimed to investigate the level of serum sTfR and its correlation with ineffective erythropoiesis and iron overload in pediatric Egyptian patients with $3-$ Thalassemia major and $\beta$ Thalassemia intermedia.

Our results reported that age of onset, symptoms and signs of hemolysis appear early in thalassemia major patients compared with thalassemia intermedia patients. This agreed with the results of [1] (Galanello and Origa, 2010) who reported that Clinical presentation of thalassemia major occurs between 6 and 24 months. Affected infants fail to thrive and become progressively pale. Feeding problems, diarrhea, irritability, recurrent bouts of fever, and progressive enlargement of the abdomen caused by spleen and liver enlargement may occur. While individuals with thalassemia intermedia present later than thalassemia major, have milder anemia and by definition do not require or only occasionally require transfusion. At the severe end of the clinical spectrum, patients present between the ages of 2 and 6 years and although they are capable of surviving without regular blood transfusion, growth and development are retarded. At the other end of the spectrum are patients who are completely asymptomatic until adult life with only mild anemia [1]

Data of the current work had reported higher incidence of splenectomy in thalassemia major patients $21(70 \%)$ as compared to thalassemia intermedia patients $6(20 \%)$. This comes in accordance with [16] Hassan et al., 2018; who did a cross 
sectional study that was carried on 73 patients with beta thalassemia. They reported that splenectomy was significantly higher in patients with thalassemia major compared to patients with thalassemia intermedia $(40.7 \%, 20 \%)$ respectively $[16]$.

Splenectomy has been performed conventionally as an adjunct or alternative to transfusion therapy. Data from observational studies suggest that splenectomy may improve growth, quality of life, and hemoglobin levels for some patients. However, data on serious adverse events after splenectomy are continuing to accumulate [17]

In addition to the accepted risk of sepsis, observational data on patients with NTDT suggest that splenectomy may be associated with a 4-7fold increased risk of overt venous thrombosis and other vascular manifestations, including pulmonary hypertension. It has also been suggested that splenectomy may reduce the body's ability to scavenge toxic free iron species. Accordingly, indications for splenectomy among patients with betathalassemia are becoming increasingly restrictive [18]

Our results showed higher significant incidence of hepatomegaly among diseased groups compared with control group. This comes in agreement with Hassan et al., 2018 who reported that hepatomegaly was present in $41(56.2 \%)$ patients of their study that of 73 thalassemic patients [16]

Hepatic diseases remain one of the most important problems among patients with thalassemia. Common causes include transfusion-related viral hepatitis (Hepatitis B, C), iron overload, drug toxicity, and biliary disease due to gallstones. Cardiac failure and rhythm disturbances remain the main cause of death among young adults with beta thalassemia major [16]

As for prevalence of hepatomegaly in thalassemic patients, variable results were obtained due to differences in studied populations and age of included patients [19]. Hashemizadeh et al., found hepatomegaly in $46 \%$ of beta thalassemia major patients with a mean age of 10.8 years. Higher percentage $(77 \%)$ of hepatomegaly was reported by [20] Caocci et al., in thalassemic patients with a median age of 10 years. On the contrary, [21] Grow et al., reported lower prevalence of hepatic complications $(6.8 \%)$ and this can be explained based on that $59.3 \%$ of their patients were below 10 years.

In our study thalassemia major patients underwent blood transfusions significantly more frequent as compared with thalassemia intermedia patients $(13.4 \pm 0.66,1.90 \pm 0.31)$ respectively. Also, thalassemia major patients had significantly higher usage of iron chelators compared with thalassemia intermedia patients $p$-value $<0.01$.

Physiologically, 1-2mg of iron is absorbed from the diet per day, with an equivalent amount lost by the turnover of gastrointestinal tract epithelial cells. The body has no mechanism for disposing of excess iron; therefore, in thalassemia and other transfusion dependent anemias, iron overload may accumulate in a relatively short time (transfusional iron overload). An RBC transfusion requirement of two units (200-250mg of iron per unit) per month will result in over $20 \mathrm{~g}$ of excess body iron in 4 years [22].

Most other iron overload patients are anemic $(\mathrm{Hb}<10 \mathrm{~g} / \mathrm{dL})$ and, therefore, particularly those who are transfusion dependent, will require iron chelation therapy in order to normalize their iron level (a transferrin saturation of $<50 \%$ and serum ferritin $<500 \mathrm{ng} / \mathrm{mL}$ ). Iron chelators remove excess iron from the plasma and the cells by binding the labile, chelatable iron, thus facilitating its excretion through the urine and feces [4].

Regarding to serum ferritin, it was significantly elevated among the diseased groups compared with control group $(p<0.01)$. Thalassemia major patients showed the highest levels $(1645 \pm 933 \mathrm{ng} / \mathrm{dl}) \mathrm{com}$ pared with thalassemia intermedia $(789 \pm 296 \mathrm{ng} / \mathrm{dl})$ patients. This agreed with the results of [23] ElShanshoury et al., 2014 who found in their study that conducted on 200 cases of children with $\beta$. thalassemia including 158 children with thalassemia major and 42 children with thalassemia intermedia. These children came from most of Egyptian Governorate with a random selection from thousand cases [23]

They reported that there was significantly lower total iron binding capacity, and significantly higher serum ferritin and serum iron, in patients with thalassemia major compared with patients with thalassemia intermedia serum ferritin was $(2857 \pm$ $146 \mathrm{ng} / \mathrm{dl})$ in thalassemia major versus $(910 \pm 123$ $\mathrm{ng} / \mathrm{dl}$ ) in thalassemia intermedia with $p$-value $<0.001)[23]$.

Chronic iron overload is the primary cause of morbidity and mortality of thalassemia patients. It results from a number of mechanisms including repetitive blood transfusion, peripheral hemolysis, increased intestinal iron absorption as well as ineffective erythropoiesis. Serum ferritin is one of the acute phase proteins that could increase in 
conditions of infections and inflammations. Although it was shown to be a poor predictor of iron load as it is affected by other conditions, serum ferritin level is still the widely and most commonly used method to asses and monitor iron load in thalassemia children. As expected, in this study the mean yearly serum ferritin was significantly higher in both thalassemia groups (TM and TI) when compared to the control group [24] .

Serum sTfR levels were significantly elevated among diseased groups compared with controls ( $p$ $<0.01$ ), and the highest values were observed in thalassemia major patients $(6.3 \pm 0.6 \mathrm{~g} / \mathrm{m})$ as compared with thalassemia intermedia patients $(4.7 \pm 0.7$ $\mathrm{g} / \mathrm{n}-1)(p<0.01)$. This means that the degree of ineffective erythropoiesis is higher in thalassemia major group compared with the thalassemia intermedia group.

These findings agree with Ragab et al., 2015 [24] who reported that serum sTfR level was higher in thalassemia major patients than thalassemia intermedia patients $(p<0.01)$ and both of TM and TI had higher sTfR level as compared to control group $(p<0.01)$.

sTfR is a soluble fragment of membrane-bound TfR that truncated from nearly all cells mostly from erythroblast and reticulocyte, has become easier to perform in the past 10 years and can be measured quantitatively. It is sensitive to represent iron availability during the erythropoietic process in bone marrow and other tissue as well as represent tissue iron status [24].

STfR is a biomarker of erythropoiesis. When SF levels are normal or high, sTfR levels reflect the erythropoietic activity [25]

Soluble transferrin receptor (sTfR) which fully reflects bone marrow erythropoietic activity, had an attractive diagnostic accuracy in predicting the risk of extramedullary hematopoiesis not only in patients with thalassemia intermedia, but also in those with thalassemia major [26].

sTfR level showed an acceptable sensitivity and specificity in predicting almost all complications and particularly those more directly linked to erythropoiesis expansion such as osteoporosis, osteopenia, extramedullary hematopoiesis and thrombosis [26]

Erythropoiesis and iron metabolism are closely interconnected. Indeed, erythropoiesis participates in systemic iron homeostasis by regulating hepcidin, which is upregulated in response to iron over- load and inflammation and downregulated by erythropoietic stimuli such as anemia, hypoxia, and EPO synthesis/administration [27].

In thalassemia, ineffective erythropoiesis induces the release of factors including growth differentiation factor 15 (GDF15), twisted gastrulation protein homolog 1 (TWSG1), Hypoxia Inducible Factor (HIF), and erythroferrone (ERFE), which can all inhibit hepcidin release. A negative correlation of GFD 15 with hepcidin corroborates the suppression of the iron regulatory protein and hepcidin [28]

Tanno et al., reported that individuals with $\beta$ thalassemia have elevated serum GDF15 levels which are positively correlated with sTfR, erythropoietin (EPO), and Serum Ferritin (SF) levels and negatively associated with hemoglobin levels [29] Tanno et al., 2007. These data suggest that excessive release of GDF 15 may suppress hepcidin production and thus dysregulate iron homeostasis in thalassemia syndromes [30] Tanno et al., 2009.

Data of the present study illustrated the the presence of a significant negative correlation between serum ferritin and age of thalassemia onset, frequency of blood transfusions, as when hemolysis present early, this will need more frequent blood transfusions, which lead to significant elevation in serum ferritin level and ultimately iron overload.

In addition, a significant negative correlation between sTfR concentration and $\mathrm{Hb}$ concentration in both $\beta$-thalassemia major and $\beta$-thalassemia intermedia. There was a strong positive correlation between sTfR and serum ferritin levels. The highest levels of sTfR and serum ferritin were observed in the thalassemia major group compared with other groups.

This confirms the possible use of soluble form of transferrin receptor as a biomarker of ineffective erythropoiesis and iron overload in patients of beta thalassemia.

In conclusion, the study confirmed that the elevated levels of serum soluble transferrin receptor are seen in situations with active erythropoiesis, such as thalassemia major and thalassemia intermedia. Also, the study confirmed that Iron status can be fully assessed by using serum ferritin, soluble transferrin receptor and hemoglobin. Soluble transferrin receptor could be used as a biomarker of ineffective erythropoiesis and iron overload in patients of beta thalassemia. 


\section{References}

1- GALANELLO R. and ORIGA R.: Beta-thalassemia. Orphanet. J. Rare Dis., May 21; 5, 2010.

2- TAHER A.T., WEATHERALL D.J. and CAPPELLINI M.D.: Thalassaemia. Lancet. Jan. 13, 391 (10116): 15567, 2018.

3- CAO A. and GALANELLO R.: Beta-thalassemia. Genet. Med., Feb., 12 (2): 61-76, 2010.

4- FIBACH E. and RACHMILEWITZ E.A.: Pathophysiology and treatment of patients with beta-thalassemia-an update. F1000 Res., 6: 2156, 2017.

5- TAHER A.T. and SALIBA A.N.: Iron overload in thalassemia: Different organs at different rates. Hematology Am. Soc. Hematol. Educ. Program., Dec. 8, (1): 265-71, 2017.

6- GUPTA R., MUSALLAM K.M., TAHER A.T. and RIVELLA S.: Ineffective Erythropoiesis: Anemia and Iron Overload. Hematology/oncology clinics of North America, 32 (2): 213-21, 2017.

7- DUKOVSKI D., LI Z., KELLY D.F., et al.: Structural and functional studies on the stalk of the transferrin receptor. Biochem. Biophys. Res. Commun. Apr., 17, 381 (4): 712-6, 2009.

8- SUEGA K., KANDARINI Y. and TUBUNG J.: Role of Soluble Transferrin Receptor and Transferrin ReceptorFerritin Index to Detect Iron Deficiency Anemia in Regular Hemodialysis Patients. Open Access Maced J. Med. Sci., 7 (1): 97-102, 2019.

9- KRAWIEC P. and PAC-KO ŻUCHOWSKA E.: Soluble transferrin receptor and soluble transferrin receptor/log ferritin index in diagnosis of iron deficiency anemia in pediatric inflammatory bowel disease. Dig. Liver Dis. Mar., 51 (3): 352-7, 2019.

10- KAWABATA HIROSHI: Transferrin and transferrin receptors update Free Radical Biology and Medicine, 133 46-54, 2019.

11- BÜYÜKKARAGÖZ B., AKGUN N.A., BULUS A.D., DURMUS AYDOGDU S. and BAL C.: Can soluble transferrin receptor be used in diagnosing iron deficiency anemia and assessing iron response in infants with moderate acute malnutrition? Arch. Argent. Pediatr., Apr. 1, 115 (2): 125-32, 2017.

12- SANDEEP SONI: Novel and innovative approaches for treatment of 3 -thalassemia Pediatric Hematology Oncology Journal (2): 121-6, 2017.

13- SKIKNE B.S.: Serum transferrin receptor. Am. J. Hematol., Nov., 83 (11): 872-5, 2008

14- SALAMA K.M., IBRAHIM O.M., KADDAH A.M., BOSEILA S., ISMAIL L.A. and HAMID M.M.: Liver Enzymes in Children with beta-Thalassemia Major: Correlation with Iron Overload and Viral Hepatitis. Open Access Maced J. Med. Sci., 3 (2): 287-92, 2015.

15- RISHI G. and SUBRAMANIAM V.N.: The relationship between systemic iron homeostasis and erythropoiesis. Biosci. Rep., 37 (6), 2017.
16- HASSAN T., ZAKARIA M., FATHY M., ARAFA M., EL GEBALY S., EMAM A. and EL GERBY K.: Association between genotype and disease complications in Egyptian patients with beta thalassemia: A Cross-sectional study. Scientific reports, 8 (1): 17730. doi: 10.1038/ s41598-018-36175-9, 2018.

17- MUSALLAM K.M., RIVELLA S., VICHINSKY E. and RACHMILEWITZ E.A.: Non-transfusion-dependent thalassemias. Haematologica, 98: 833-44, 2013.

18- CAPPELLINI M.D., PORTER J.B., VIPRAKASIT V. and TAHER A.T.: A paradigm shift on beta-thalassaemia treatment: How will we manage this old disease with new therapies? Blood Rev., Jul., 32 (4): 300-11, 2018.

19- HASHEMIZADEH H., NOORI R. and KOLAGARI S.H.: Assessment Hepatomegaly and liver Enzymes in 100 Patients with beta Thalassemia Major in Mashhad, Iran. Iran J. Ped. Hematol. Oncol., 2: 171-7, 2012.

20- CAOCCI G., et al.: Health related quality of life in Middle Eastern children with beta-thalassemia. BMC Blood Disorders, 12, 6, 2012.

21- GROW K., ABROL P., VASHIST M., YADAV R. and SHARMA S.: Associated Complications In Beta Thalassemia Patients. IOSR Journal of Pharmacy, 3: 22-5, 2013.

22- HELLSTRÖM-LINDBERG E.: Management of anemia associated with myelodysplastic syndrome. Semin. Hematol., 42 (2 Suppl 1): S10-3, 2005.

23- EL-SHANSHORY M., HAGAG A., SHEBL S., BADRIA I., ABD ELHAMEED A., ABD EL-BAR E. and SHARAF E.: Spectrum of Beta Globin Gene Mutations in Egyptian Children with 3 -Thalassemia. Mediterranean Journal of Hematology and Infectious Diseases, 6 (1), 2014.

24- RAGAB S.M., SAFAN M.A. and BADR E.A.: Study of serum haptoglobin level and its relation to erythropoietic activity in Beta thalassemia children. Mediterranean Journal of Hematology and Infectious Diseases, 7 (1), 2015.

25- GINZBURG Y. and RIVELLA S: “ $\beta$-thalassemia: A model for elucidating the dynamic regulation of ineffective erythropoiesis and iron metabolism," Blood, Vol. 118, No. 16, pp. 4321-30, 2011.

26- RICCHI P., AMMIRABILE M., COSTANTINI S., SPASIANO A., Di MATOLA T., VERNA R., PEPE A., CINQUE P., SAPORITO C., FILOSA A. and PAGANO L.: Soluble form of transferrin receptor as a biomarker of overall morbidity in patients with non-transfusion dependent thalassaemia: A cross-sectional study. Blood Transfus. Nov., 14 (6): 538-40, 2016.

27- GARDENGHI S.R., GRADY W. and RIVELLA S.: "Anemia, ineffective erythropoiesis, and hepcidin: Interacting factors in abnormal iron metabolism leading to iron overload in $\beta$-thalassemia," Hematology/Oncology Clinics of North America, Vol. 24, No. 6, pp. 1089-107, 2010.

28- HUANG Y., LIU R., WEI X., LIU J., PAN L., YANG G. and LAI Y.: Erythropoiesis and Iron Homeostasis in Non -Transfusion-Dependent Thalassemia Patients with Extramedullary Hematopoiesis. BioMed research international, 4504302. doi: 10.1155/2019/4504302, 2019. 
29- TANNO T., BHANU N.V., ONEAL P.A., et al.: "High levels of GDF15 in thalassemia suppress expression of the iron regulatory protein hepcidin," Nature Medicine, Vol. 13, No. 9, pp. 1096-101, 2007.
30- TANNO T., PORAYETTE P., SRIPICHAI O., et al.: "Identification of TWSG1 as a second novel erythroid regulator of hepcidin expression in murine and human cells," Blood, Vol. 114, No. 1, pp. 181-6, 2009.

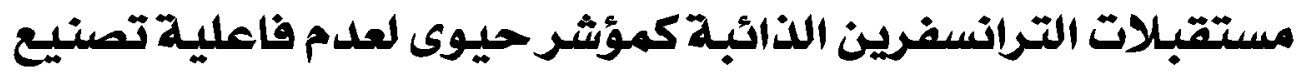

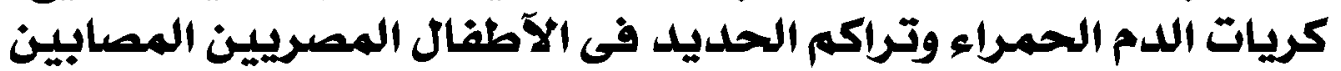

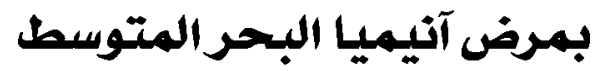

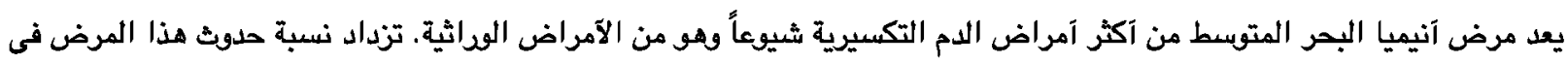

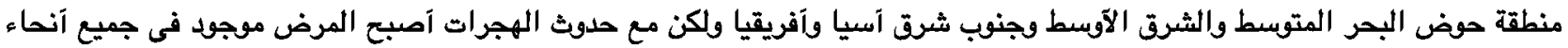
العالم.

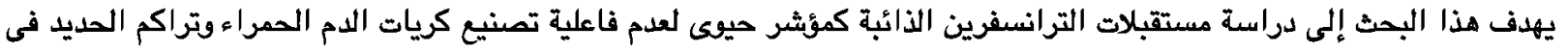

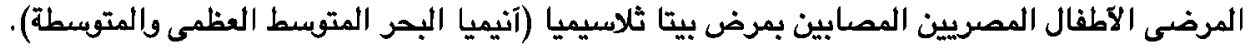
شملت الدراسة عدد •9 طفلأتم تقسيمهم إلى ثلاك مجموعات:

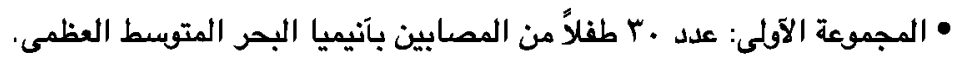

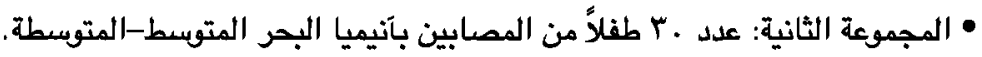

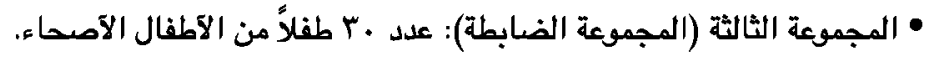

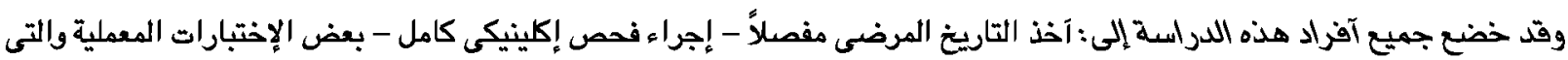

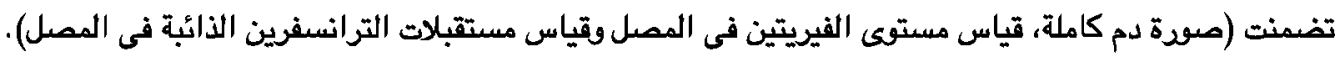
وقد آسفرت هذه الدراسة عن النتائج الآثية: • إرتفاع تركيز مستوى الفيريتين فى الممل في حالات آنيميا البحر المتوسط محل الدراسة وخاصة آنيميا البحر المتوسط العظمى.

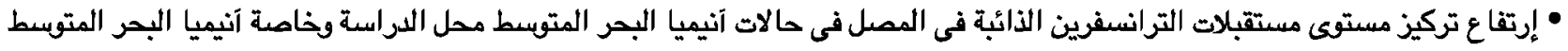
العظمى ويرجع ذلك إلى زيادة تصنيع كريات الدم الحمراء النئ التير فعالة.

• وجود علاتة إرتباط عكسية بين مستوى الهيموجلوبين ومستوى مستقبلات الترانسفرين الذائبة فى المصل فى حالات آنيميا البحر المتوسط.

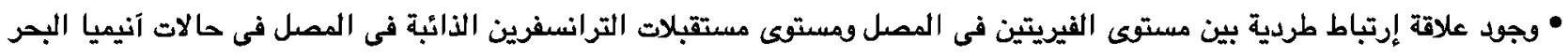

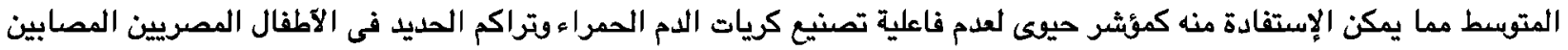
بمرض آنيميا البحر المتوسط.

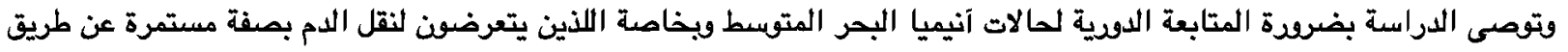

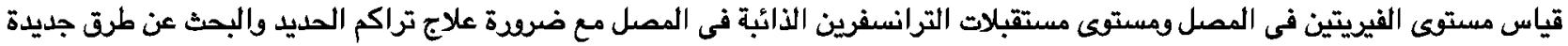

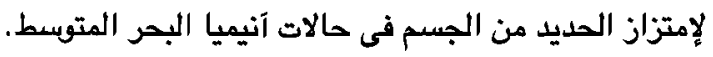

